\title{
Pantangan Makanan pada Suku Muyu di Papua
}

\section{The Food Taboo of the Muyu Tribe in Papua}

\author{
Agung Dwi Laksono ${ }^{1}$, Ratna Dwi Wulandari2*
}

\begin{abstract}
ABSTRAK
Latar Belakang: Makanan bagi suku Muyu merupakan aktualisasi kehidupan sehari-hari atas kepercayaan pada dimensi religius yang dianut dan dihayati. Studi ditujukan untuk mengeksplorasi tabu makanan pada suku Muyu di Indonesia. Metode: Studi kasus dilakukan di Distrik Mindiptana, Kabupaten Boven Digoel, Papua. Pengumpulan data dilakukan dengan observasi partisipatif, wawancara mendalam, dan penelusuran dokumen. Penulisan dilakukan dengan pendekatan etnografi dalam perspektif emik.

Hasil: Kepercayaan pada penguasa hewan liar, penguasa buah-buahan dan tumbuhan, dan penguasa sagu, begitu kental, sehingga muncul banyak mantra untuk berburu dan mencari makan di hutan, yang merupakan bentuk pengakuan atas kekuatan tersebut. Suku Muyu memiliki batasan pada beberapa jenis makanan. Makanan bisa menjadi tabu berdasarkan bentuk fisiknya. Selain itu, karena kepercayaan masyarakat Muyu bahwa bahan makanan tersebut memiliki kualitas yang buruk. Tabu makanan bagi laki-laki terutama terkait erat dengan praktik ritual sebagai proses menjalani inisiasi sebagai tómkót (big man). Makanan tabu bagi wanita itu ditujukan untuk ibu yang sedang hamil dan menyusui. Pantang bagi ibu Muyu yang sedang hamil ternyata kerap dikaitkan dengan janin di dalam kandungan. Tabu makanan untuk anak-anak, terutama untuk anak laki-laki, ternyata hampir sama dengan pantangan bagi laki-laki Muyu dewasa. Pantang ini berlaku bagi anak laki-laki yang dipersiapkan untuk menjadi tómkót, terutama saat menjalani proses inisiasi.

Kesimpulan: Tabu makanan berlaku untuk semua orang Muyu. Bagi pria, sangat erat kaitannya dengan praktik ritual sebagai proses menjalani inisiasi sebagai tómkót. Bagi wanita, ditujukan bagi ibu yang sedang hamil dan menyusui. Bagi anak-anak, terutama untuk anak laki-laki, hampir sama dengan pantangan bagi pria dewasa.
\end{abstract}

Kata kunci: Etnografi Kesehatan, Kehamilan, Rantai Makanan, Suku Muyu, Makanan Pantangan

\section{ABSTRACT}

Background: Food for the Muyu tribe was an actualization of daily life over the belief in the religious dimension that is adopted and lived. This study aims to explore the food taboo among the Muyu tribe in Indonesia.

Methods: The authors conducted the case study in Mindiptana, Boven Digoel, Papua. The study carried out data collection by participatory observation, in-depth interviews, and document searches. The authors carried out the report using an ethnographic approach an emically perspective.

Results: Belief in the lord of wild animals, the lord of fruits and plants, and the lord of sago, was so thick that many spells appear to hunt and search for food in the forest, which was a form of recognition of the power of these. The Muyu tribe had restrictions on several types of food. Food can be taboo based on its physical form; meanwhile, because of Muyu people's belief that there was a bad quality inherent in these food ingredients. It was especially closely related to ritual practice for men as a process of undergoing initiation as a big man. The Muyu intended women taboo for mothers who are pregnant and breastfeeding. Abstinence for pregnant Muyu women was often related to the fetus in the womb. For children, especially for boys, it was almost the same as abstinence for adult Muyu men. This abstinence applies to boys who were prepared to be tómkót, especially when undergoing the initiation process.

Conclusions: The food taboo applies to all Muyu people, both men, women, and children.

Keywords: Food Chain, Food Taboo, Health Ethnography, Muyu Tribe, Pregnancy

*Korespondensi:

ratna-d-w@fkm.unair.ac.id

Ratna Dwi Wulandari

Fakultas Kesehatan Masyarakat-Universitas Airlangga Kampus C Mulyorejo, Surabaya 60115, Indonesia

Diterbitkan oleh Universitas Airlangga dan IAGIKMI 


\section{PENDAHULUAN}

Makanan pantangan berkaitan dengan jenis makanan tertentu yang harus kita hindari. Secara khusus, hal ini berkaitan dengan kepercayaan dan isu-isu magisreligius. Beberapa suku melakukannya untuk melestarikan sumber daya alam, sementara beberapa lainnya untuk membuat ritual khusus lebih berkesan magis. Secara umum, pantangan makanan dapat memperkuat identitas dan kohesi kelompok atau budaya tertentu ${ }^{1}$.

Pantangan makanan adalah bagian dari kepercayaan dan praktik budaya. Sementara itu, masyarakat mewariskan pantangan makanan dari satu generasi ke generasi berikutnya. Proses ini berbarengan dengan pewarisan unsur budaya lainnya. Proses pewarisan kepercayaan terkait pantangan makanan antar generasi ini menjelaskan konsistensi pantangan makanan yang berlaku pada beberapa suku ${ }^{2,3}$. Selain di tingkat individu, pantangan makanan juga berlaku di tingkat komunal, terutama di masyarakat yang masih kental dengan tradisi ${ }^{4}$. Individu juga dapat berpantang makanan dalam suatu kelompok kekerabatan, hal ini untuk memanifestasikan diri mereka sebagai tetua adat ${ }^{1}$.

Di suku-suku tertentu, mereka percaya makanan tabu memiliki konsekuensi berbahaya bagi mereka yang melanggar batasan ini. Makanan pantangan bagi ibu hamil, misalnya, diyakini dapat mempengaruhi bayi yang akan dilahirkan. Masyarakat Jawa melarang ibu hamil makan nasi goreng, durian, nangka, nanas, dan tebu. Orang Jawa percaya makanan ini menyebabkan komplikasi saat melahirkan². Ibu hamil suku Madura di Indonesia pantang makan cumi, udang, nanas, ambarela, kol, air dingin. Orang Madura percaya bahwa makanan ini memiliki efek buruk pada janin dalam kandungan ${ }^{5}$. Wanita etnis Tengger di Jawa Timur, Indonesia, berpantang makanan yang dianggap tidak biasa, seperti makanan lengket atau kembar. Situasi tersebut karena adanya pendekatan simbolik, fungsional, dan religius atau nilai. Jika wanita Tengger mengkonsumsi makanan jenis ini, mereka percaya akan melahirkan anak sesuai dengan ciri fisiknya. Selain itu, ibu hamil Tengger juga harus menghindari makanan panas. Jenis makanan tersebut adalah cabai, merica, nanas, dan tape (makanan fermentasi). Suku Tengger percaya jenis makanan ini menyebabkan janin kepanasan dan bisa menyebabkan keguguran $^{6,7}$. Sementara, mitos di Nigeria Tenggara melarang anak-anak setempat mengonsumsi daging bekicot. Ada ketakutan bahwa anak-anak akan berjalan seperti siput ${ }^{8}$.

Suku Muyu adalah salah satu dari lebih 250 suku yang mendiami pulau Papua di wilayah administrasi Negara Kesatuan Republik Indonesia ${ }^{9}$. Bagi orang Muyu, makanan menempati posisi yang begitu penting. Makanan bagi kaum Muyu tidak bisa dilepaskan begitu saja sebagai sumber energi, atau nutrisi, atau untuk memenuhi kebutuhan hidup. Pangan bagi suku Muyu memiliki nilai yang sentral, yang juga merupakan aktualisasi kehidupan sehari-hari bagi keyakinan pada dimensi keagamaan yang dianut dan dihayati. Suku Muyu yang tinggal di pedalaman Papua bagian Selatan seringkali mengandalkan hutan sebagai lumbung makanan. Mereka menyediakan makanan pokok hutan, sayuran, dan lauk pauk dengan sedikit usaha. Pola pengumpulan makanan dalam kehidupan masyarakat Muyu ini erat kaitannya dengan dimensi keagamaan yang berkembang lebih awal sebelum masa misi Katolik merasuki kehidupan masyarakat Muyu ${ }^{10}$. Dalam catatan Schoorl, kepercayaan pada penguasa hewan liar (kómòt), penguasa buah dan tumbuhan (tànggítmàn di Kawangtet, atau tátámàn di Yibi, atau anòngkólumki di Tumutu, atau ambènànkítàn di Woropko dan Katanam). Mereka juga percaya penguasa sagu (kòngki), begitu dalam kepercayaan tersebut, begitu banyak waruk (kesaktian) berupa mantra muncul, untuk berburu dan mencari makanan di hutan, yang merupakan bentuk pengakuan akan kekuatan makhluk gaib ini ${ }^{11}$. Berdasarkan uraian latar belakang, penelitian ini bertujuan untuk mengeksplorasi pantangan makanan di kalangan suku Muyu di Indonesia.

\section{METODE}

Artikel ini disusun untuk mengupas tentang pantangan makanan yang berlaku bagi suku Muyu di Indonesia. Eksplorasi meliputi jenis makanan, orang yang harus berpantang, dan akibat atau dampak dari pelanggaran larangan tersebut.

Studi ini menyusun artikel sebagai studi kasus makanan pantangan secara mendalam pada masyarakat adat Muyu. Penulis mewawancarai sekitar 40 peserta yang terdiri dari tokoh masyarakat, tokoh agama, tokoh adat, ibu rumah tangga, pekerja pendatang, dan remaja, dengan menggunakan teknik snowball sampling.

Penulis melakukan studi kasus di Kecamatan Mindiptana, Kabupaten Boven Digoel, Provinsi Papua, Indonesia. Kecamatan Mindiptana merupakan wilayah administrasi setingkat kecamatan yang paling banyak didiami oleh Suku Muyu dibandingkan dengan kecamatan lain di sekitarnya. Pengumpulan data dilakukan dengan observasi partisipatif dan wawancara mendalam. Peneliti tinggal di tengah-tengah masyarakat suku Muyu (live in) selama dua bulan. Selain itu, penelitian melakukan penelusuran dokumen untuk melengkapi konteks budaya Muyu. Penelitian melakukan pengumpulan data pada bulan Mei-Juni tahun 2014. Penulis melakukan penulisan dengan menggunakan pendekatan etnografi. Lebih lanjut, penulis menggunakan pendekatan penulisan emik sesuai dengan perspektif masyarakat Muyu ${ }^{12,13}$.

\section{HASIL DAN PEMBAHASAN}

Suku Muyu: Masyarakat Cerdas dalam Lingkaran Belief Pada masa penjajahan Belanda, suku Muyu mendiami kawasan kaki bukit dan lembah-lembah kecil. Diantaranya kawasan Sentani, Nimboran, dan Ayamaru. Suku Muyu menempati wilayah Onderafdeling Muyu (setara dengan distrik) di sebidang tanah sempit hampir berbentuk bujur sangkar di sepanjang perbatasan Papua Nugini. Sebagian kecil dari kelompok etnis itu menempati wilayah tetangga Papua Nugini ${ }^{11}$. Saat ini, suku Muyu hidup tersebar di beberapa daerah. Namun koloni terbesar suku Muyu berada di sekitar Distrik Mindiptana yang merupakan ibu kota Onderafdeling Muyu pada zaman Belanda. Secara administratif, Kecamatan Mindiptana merupakan bagian dari Kabupaten Boven Digoel ${ }^{14}$. 
Sejak zaman pemerintahan kolonial Belanda, suku Muyu sudah dikenal memiliki mental dan daya saing yang baik dibandingkan dengan suku-suku lain di wilayah Papua. Orang Muyu yang bertubuh tinggi banyak yang menjadi pejabat di pemerintahan Kabupaten Boven Digoel, termasuk di beberapa kabupaten tetangga di bagian Selatan Provinsi Papua ${ }^{11,15}$.

Meski akses transportasi dan informasi sudah mulai terbuka di wilayah suku Muyu, kepercayaan tentang hal-hal magis tetap ada, termasuk kepercayaan yang berkaitan dengan kesehatan. Misalnya, masyarakat Muyu percaya darah persalinan dan darah haid dari wanita Muyu membawa udara kotor supranatural yang buruk, yang biasa disebut iptém dalam bahasa Muyu. Orang Muyu percaya bahwa iptém menyebabkan hal-hal buruk bagi orang-orang di sekitarnya, termasuk keluarga, terutama laki-laki. Pengaruh iptém bisa berupa hosa (sesak napas), persendian membiru, hingga kematian. Untuk itu, pihak keluarga mengasingkan ibu-ibu Muyu yang sedang melahirkan dari rumah tersebut. Keluarga membuat gubuk terpisah sekitar 25 meter dari rumah untuk wanita Muyu. Wanita Muyu yang melahirkan akan tinggal di tempat itu hingga 40 hari $^{14,15}$.

Kepercayaan kesehatan seperti itu tidak hanya diyakini dan berlaku bagi masyarakat biasa suku Muyu, tetapi juga diyakini dan berlaku bagi tenaga kesehatan. Mereka adalah penduduk asli Muyu yang telah mengenyam pendidikan kedokteran modern. Namun kenyataannya dalam kehidupan sehari-hari masih sangat mempercayai kepercayaan kesehatan yang melingkupi kehidupan masyarakat Muyu ${ }^{16}$.

Kepercayaan lain yang mendominasi kehidupan sehari-hari masyarakat Muyu adalah waruk. Masyarakat Muyu percaya bahwa waruk adalah kesaktian yang harus dimiliki oleh orang Muyu. Waruk adalah simbol keberanian bagi seorang pria suku Muyu. Seorang pria Muyu yang tidak memiliki waruk, yang didapatkan melalui inisiasi, belum menjadi seorang pria Muyu; dia masih "perempuan". Waruk seringkali berupa mantra-mantra rahasia, yang bahkan saudara kandungnya tidak mengetahui tentang mantra-mantra yang dimiliki saudaranya. Waruk bersifat personal. Hanya

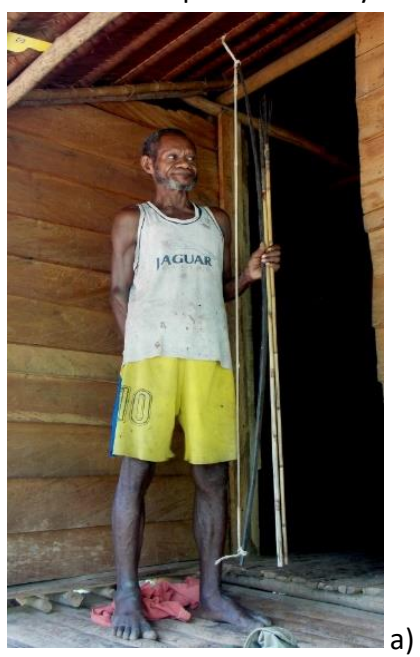

Gambar 1. Peralatan Berburu Suku Muyu

a) Laki-laki Muyu dengan Alat Berburunya;

b) Peralatan Berburu. pria itu dan guru spiritual yang segera memahami mantra waruk yang dia miliki ${ }^{15,17}$

Waruk untuk laki-laki Muyu dapat berasal dari orang tuanya yang merupakan keturunan langsung, diperoleh dari seorang tetua adat melalui proses inisiasi, atau diperoleh melalui usahanya sendiri. Waruk yang melalui usaha sendiri biasanya berupa jimat atau benda sakti. Proses inisiasi harus dilalui untuk mendapatkan waruk dari tetua adat. Masyarakat Muyu percaya bahwa sesepuh memiliki kemampuan spiritual, dan hasl tersebut berlangsung sangat rahasia. Cukup menantang untuk mendapatkan detail tentang proses inisiasi ini. Siapapun yang berani membicarakan inisiasi kepada yang tidak seharusnya, apalagi suku lain, akan terkena kutukan sampai mati ${ }^{15,17}$.

\section{Makanan}

Mayoritas masyarakat Muyu mengandalkan hasil hutan untuk memenuhi kebutuhan pangan seharihari. Ada yang berburu, mengumpulkan hasil hutan, memelihara babi, dan mencari ikan di sungai. Sebagian kecil lainnya adalah bercocok tanam dan menyadap getah karet dari sisa-sisa pohon karet pada zaman Belanda.

Dalam teknologi pengolahan makanan, suku Muyu tertinggal dari suku-suku di wilayah Indonesia lainnya. Masyarakat Muyu masih terbiasa memasak dengan menggunakan kulit kayu, daun, dan bambu sebagai media atau alat pengolah makanan. Tidak sampai dua dekade yang lalu, mereka berkenalan dengan peralatan memasak modern semacam panci, wajan, sendok, dan peralatan masak logam lainnya.

Suku Muyu memiliki peralatan masak yang unik, yang terpisah antara tungku perempuan (Gambar 2.a dan Gambar 2.b) dan tungku laki-laki (Gambar 2.c). Tungku perempuan ditempatkan di dapur keluarga, sedangkan tungku laki-laki ditempatkan di kamar lakilaki, biasanya di ruang utama. Tungku laki-laki hanya berfungsi untuk memasak makanan ringan sederhana, seperti untuk membakar batatas (ubi) dan kasbi (singkong)

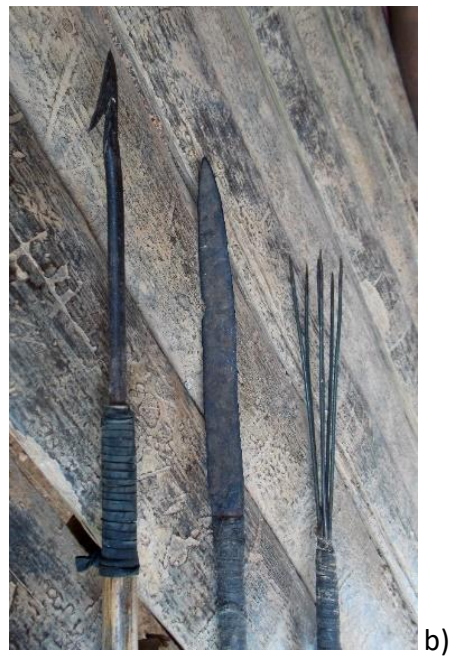




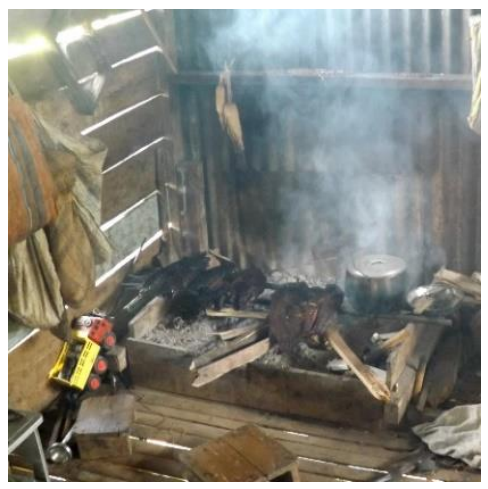

a)

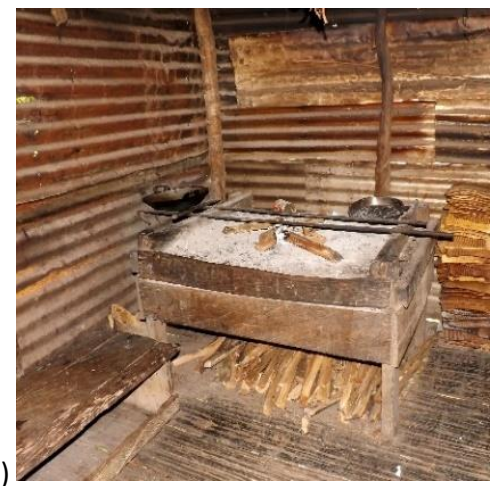

Gambar 2. Tungku Memasak Suku Muyu;

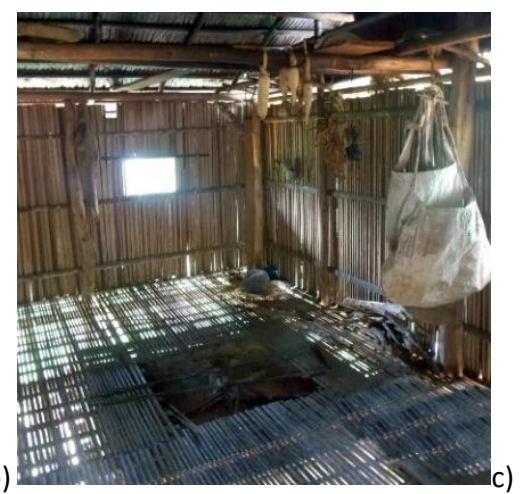

a) Tungku Perempuan Model Duduk; b) Tungku Perempuan Model Berdiri; c) Tungku Laki-laki.

Sumber: Dokumentasi Peneliti

\section{Makanan Pantangan Suku Muyu}

Suku Muyu memiliki pantangan terhadap beberapa jenis makanan. Hambatan makanan ini berlaku untuk pria dan wanita, baik anak-anak maupun orang dewasa. Makanan bisa dibilang tabu berdasarkan bentuk fisiknya, selain karena kepercayaan masyarakat Muyu bahwa ada kualitas buruk yang melekat pada bahan makanan tersebut. Mereka sering menggunakan makanan yang dianggap panas sebagai alasan.

Tabu makanan untuk pria paling erat kaitannya dengan praktik ritual karena menjalani inisiasi sebagai tómkót. Tómkót adalah profil big man bagi Suku Muyu. Tómkót adalah profil pemimpin yang sempurna bagi Suku Muyu. Dia berwibawa, dihormati karena kepribadiannya; aura itu muncul dari dalam dirinya. Situasinya berbeda dengan kawab, yang juga merupakan salah satu profil pemimpin Muyu. Hanya saja kawab bisa mendapatkan kepemimpinannya melalui kekayaan dan kekuasaan dan bahkan bisa bertindak kasar untuk mencapai tujuannya ${ }^{11}$. Jenis pantangan makanan untuk tómkót adalah ikan sembilang, udang biru, kuskus, dan ular. Jika seorang pria berani mengambil risiko untuk memakan pantangan ini, maka aura kepemimpinannya dapat memudar, karena itu berarti laki-laki Muyu tersebut tidak dapat menahan diri. Kemampuan menahan diri adalah salah satu keutamaan tómkót bagi big man Suku Muyu. Jika laki-laki Muyu melanggar pantangan makanan tersebut, kekuatan gaib (waruk) mereka bisa berkurang, dan bahkan hilang ${ }^{10}$.

Masyarakat Muyu sering kali memaksudkan pantangan makanan bagi perempuan yang sedang hamil dan menyusui. Pantang bagi ibu hamil Muyu sering dikaitkan dengan janin dalam kandungan. Setidaknya ada sebelas jenis makanan dari hewan dan dua jenis buah atau sayuran yang wajib dihindari oleh kaum muyu sebagai pantangan bagi ibu hamil dan menyusui. Jenis makanan tersebut adalah ikan sembilang - secara fisik mirip dengan ikan lele tetapi lebih bulat dan bentuknya kuning. Kemudian tabu lainnya adalah ikan tònkòròm atau ikan perut kuning, penyu, buaya, kaluang (kelelawar), burung mamruk, kasuari, telur kasuari, onkéwét (tawon), telur ayam hutan, tuban (tikus hutan), kuskus, dan ular. Sementara makanan pantangan dari jenis tumbuhan adalah pandan kuning, pandan hijau, mentimun, dan kacang panjang.

Ikan sembilang adalah amóp (dilarang), yang dilarang keras dikonsumsi oleh ibu hamil karena orang Muyu khawatir bayi yang dikandungnya akan memiliki penampilan fisik seperti ikan sembilang. Bayi akan lahir dengan kepala lebih besar dari tubuhnya. Mereka khawatir bayi akan kesulitan keluar dari jalan lahir ibunya. Jenis ikan lain yang harus dihindari wanita Muyu adalah ikan tònkòròm (ikan perut kuning). Wanita hamil dan ibu menyusui sama-sama tidak mengkonsumsi tònkòròm. Ikan yang hidup di air tawar, menurut kepercayaan masyarakat Muyu, terutama Muyu bagian atas, dapat menyebabkan keluarnya darah dari hidung bayi atau anak.

Sedangkan buaya dijadikan tabu bagi ibu hamil Muyu karena dikhawatirkan bayi atau janin yang dikandungnya akan mati di dalam kandungan, ketika dikonfirmasi mengenai penyebab terjadinya hal tersebut, informan menjawab tidak tahu. Mereka hanya percaya bahwa amóp (dilarang), yang mereka tanamkan sejak dahulu kala, tanpa disertai dengan informasi tentang konsekuensi dari mengkonsumsinya. Kura-kura juga merupakan salah satu jenis makanan hewani yang harus dihindari ibu hamil. Dikhawatirkan induk bayi Muyu yang lahir akan mirip secara fisik dengan kura-kura yang memiliki leher kepala sangat pendek.

Suku Muyu melarang mengkonsumsi hewan yang bisa terbang bagi ibu hamil dan menyusui. Terdiri dari kaluang atau kelelawar, burung mamruk, kasuari, dan burung tawon-tawon (onkéwét). Kaluang ini cukup besar, seukuran kucing dewasa. Kaluang dijadikan pantangan bagi ibu hamil karena dikhawatirkan bayi yang dikandungnya akan bergelantungan seperti kelelawar di pohon, sehingga berkembang keyakinan bahwa bayi akan sulit keluar. 

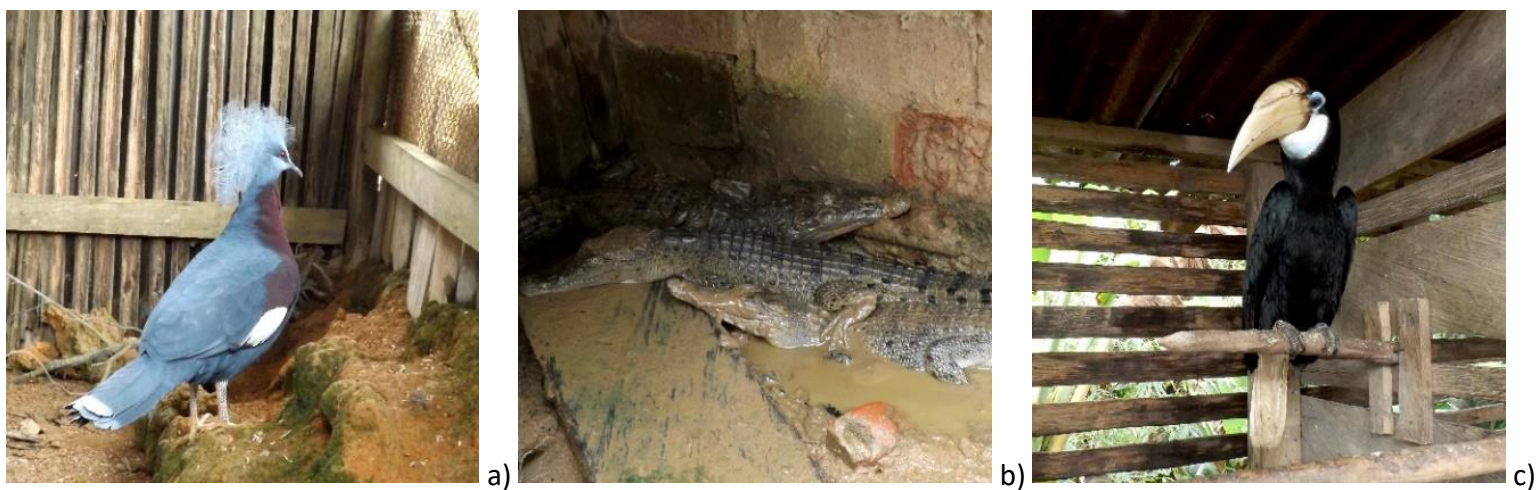

Gambar 3. Beberapa Makanan Pantangan pada Suku Muyu

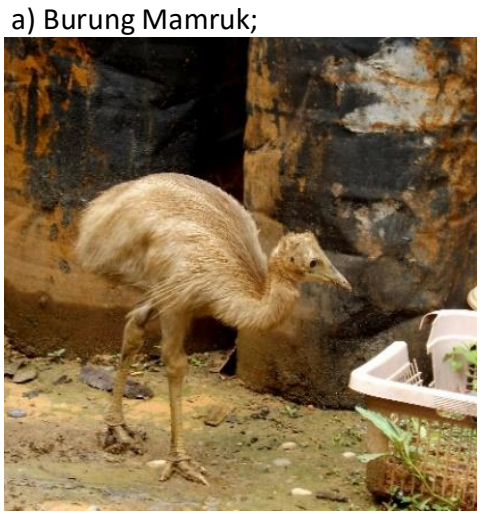

b) Buaya;

c) Burung Tawon-tawon (onkéwét);
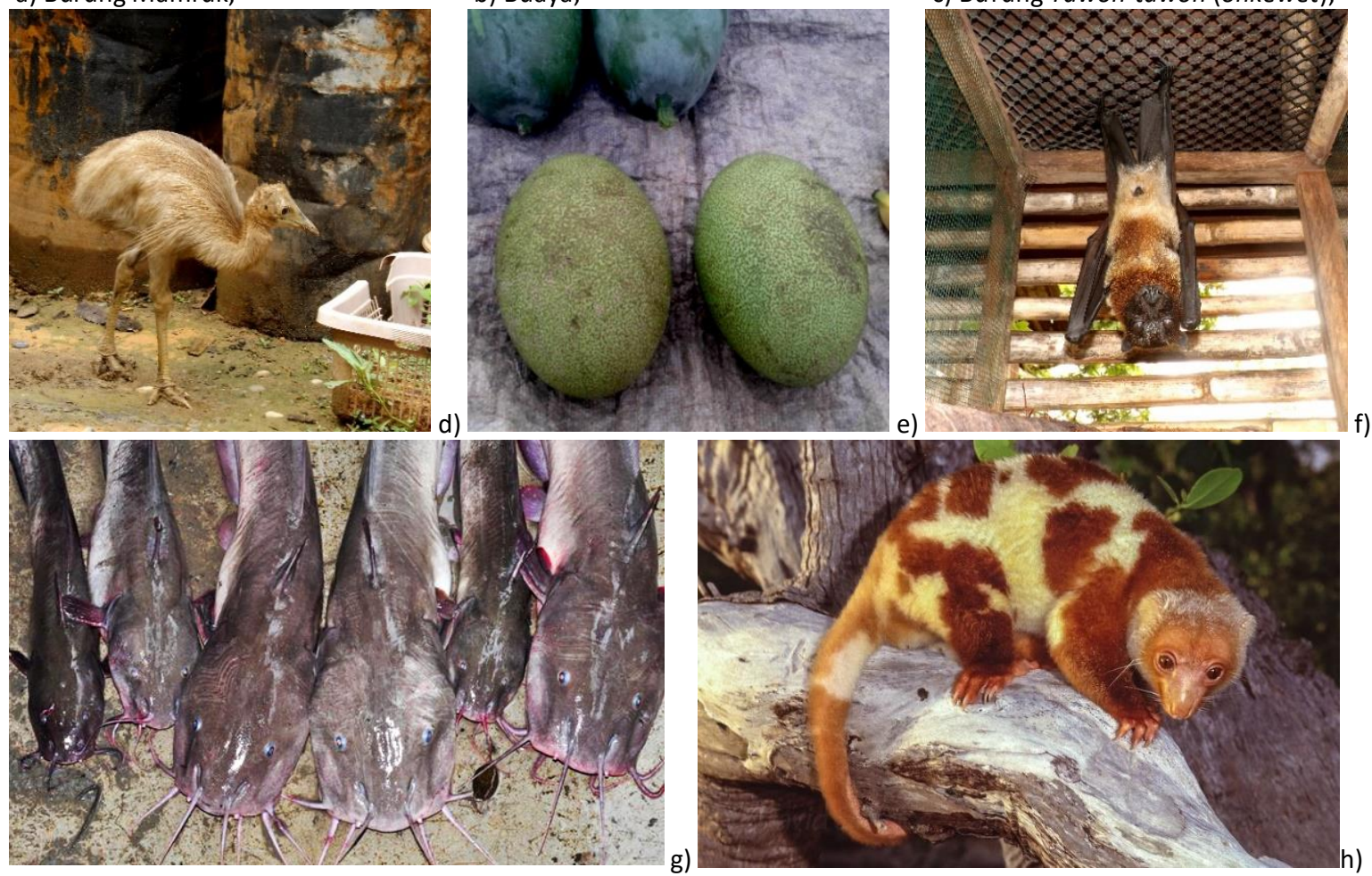

e)

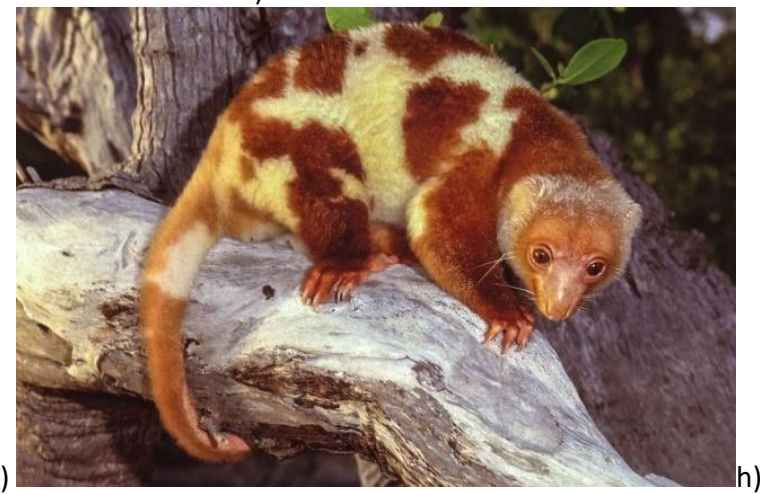

Gambar 3. Beberapa Makanan Pantangan pada Suku Muyu;

d) Burung Kasuari; e) Telur Kasuari; f) Kaluang (kelelawar); g) Ikan Sembilang; h) Kuskus.

Sumber: Dokumentasi Peneliti (3a-f); Kabarmancing.com (3g); idntimes.com (3h).

Suku Muyu menggunakan burung cantik kebiruan dan bermahkota, burung mamruk, sebagai pantangan bagi ibu hamil, ibu menyusui, dan anak-anak. Hal yang tabu karena masyarakat Muyu percaya bahwa bayi yang dikandung oleh perempuan Muyu akan memiliki kelainan pada anggota tubuh mereka ketika mereka dilahirkan nanti, sehingga ketika berjalan, mereka terlihat sangat lambat, seperti burung mamruk.
Burung kasuari, termasuk telurnya, juga tabu bagi ibu hamil dan menyusui. Di suku Muyu, ada kepercayaan yang berkembang bahwa kasuari dapat membuat bayi yang dikandung oleh seorang wanita Muyu yang lahir mono (tuli-bisu), seperti kasuari, yang hanya menoleh kiri-kanan, hanya bisa menatap matanya, tetapi tidak bisa mendengar. Pantangan juga berlaku untuk telur kasuari. 
Tabel 1. Makanan Pantangan Suku Muyu

\begin{tabular}{|c|c|c|}
\hline Sasaran & Jenis Makanan & Alasan Pantangan \\
\hline \multirow[t]{4}{*}{ Laki-laki } & Ikan Sembilang & Kesaktian (waruk) dapat berkurang atau menghilang \\
\hline & Udang Biru & Kesaktian (waruk) dapat berkurang atau menghilang \\
\hline & Kuskus & Kesaktian (waruk) dapat berkurang atau menghilang \\
\hline & Ular & Kesaktian (waruk) dapat berkurang atau menghilang \\
\hline Sasaran & Jenis Makanan & Alasan Pantangan \\
\hline \multirow{15}{*}{$\begin{array}{l}\text { Perempuan Hamil } \\
\text { dan Menyusui }\end{array}$} & Ikan Sembilang & Bayi akan lahir dengan kepala yang lebih besar dari badannya \\
\hline & $\begin{array}{l}\text { Ikan Tònkòròm (Ikan } \\
\text { perut kuning) }\end{array}$ & $\begin{array}{l}\text { Makanan tersebut dapat menyebabkan darah keluar dari hidung bayi } \\
\text { atau anak }\end{array}$ \\
\hline & Kura-kura & $\begin{array}{l}\text { Bayi yang lahir secara fisik akan mirip dengan kura-kura, yang memiliki } \\
\text { leher kepala sangat pendek }\end{array}$ \\
\hline & Buaya & Bayi atau janin yang dikandungnya akan mati di dalam rahim \\
\hline & Kaluang (kelelawar) & $\begin{array}{l}\text { Mereka takut bayi yang dikandungnya akan menggantung seperti } \\
\text { kelelawar di pohon. Bayi akan kesulitan untuk keluar }\end{array}$ \\
\hline & Burung Mamruk & $\begin{array}{l}\text { Bayi tersebut akan mengalami kelainan pada anggota tubuhnya saat } \\
\text { dilahirkan nanti, sehingga saat berjalan terlihat sangat lamban, seperti } \\
\text { mamruk. }\end{array}$ \\
\hline & $\begin{array}{l}\text { Burung Kasuari } \\
\text { (termasuk telurnya) }\end{array}$ & $\begin{array}{l}\text { Makanan tersebut bisa membuat bayi yang dikandung oleh seorang } \\
\text { wanita Muyu terlahir mono (tuli-bisu). Sama seperti kasuari, yang hanya } \\
\text { bisa menoleh kiri-kanan, hanya bisa menatap matanya, tapi tidak bisa } \\
\text { mendengar }\end{array}$ \\
\hline & Onkéwét (Tawon) & $\begin{array}{l}\text { Makanan juga bisa memiliki efek mono (bisu) pada bayi yang } \\
\text { dilahirkannya }\end{array}$ \\
\hline & Burung Kauni (Beo) & Makanan bisa membuat orang cepat tua karena rambut lebih cepat putih \\
\hline & Telur ayam hutan & Makanannya gampang membuat badan anak kecil panas dan kulit gatal \\
\hline & Tuban (tikus hutan) & $\begin{array}{l}\text { Makanan tersebut dapat membuat tubuh yang mengkonsumsinya } \\
\text { menjadi demam atau panas tinggi }\end{array}$ \\
\hline & Kuskus & Suku Muyu takut memiliki anak hanya sebatas dua anak, seperti kuskus \\
\hline & $\begin{array}{l}\text { Òmdik birim (kuskus } \\
\text { kuning) }\end{array}$ & $\begin{array}{l}\text { Makanan mempengaruhi bayi yang lahir dari ibu Muyu secara negatif; } \\
\text { Orang Muyu mengira itu akan membuat anak-anak mereka berkulit } \\
\text { kuning }\end{array}$ \\
\hline & $\begin{array}{l}\text { Anup kunim (jenis } \\
\text { ular) }\end{array}$ & $\begin{array}{l}\text { Makanan tersebut dapat mendorong tumbuh kembang anak menjadi } \\
\text { terganggu dan lambat tumbuh }\end{array}$ \\
\hline & $\begin{array}{l}\text { Pandan kuning atau } \\
\text { pandan hijau }\end{array}$ & $\begin{array}{l}\text { Makanan dapat menyebabkan anak yang lahir atau disusui mengalami } \\
\text { gangguan bicara atau masalah bicara }\end{array}$ \\
\hline \multirow{2}{*}{ Sasaran } & Jenis Makanan & Alasan Pantangan \\
\hline & Mentimun & $\begin{array}{l}\text { Tidak didapatkan informasi yang jelas tentang efek atau dampak jika } \\
\text { wanita muyu mengkonsumsi sayuran jenis ini }\end{array}$ \\
\hline \multirow[t]{2}{*}{$\begin{array}{l}\text { Perempuan Hamil } \\
\text { dan Menyusui }\end{array}$} & Kacang panjang & $\begin{array}{l}\text { Makanan tersebut dapat menyebabkan ASI menjadi kering, sehingga } \\
\text { tidak dapat menyusui bayinya }\end{array}$ \\
\hline & $\begin{array}{l}\text { Gnemo (daun } \\
\text { melinjo/gnetum) }\end{array}$ & $\begin{array}{l}\text { Karena bayi dalam kandungan dapat diganggu oleh déma (roh) penjaga } \\
\text { kétpòn (tempat suci) }\end{array}$ \\
\hline $\begin{array}{l}\text { Perempuan } \\
\text { menstruasi }\end{array}$ & Babi & $\begin{array}{l}\text { Makanannya bikin darah haid keluar lebih banyak dari biasanya, sehingga } \\
\text { haid bisa lebih lama }\end{array}$ \\
\hline \multirow[t]{3}{*}{ Anak-anak } & Onkéwét (tawon) & Bisa membuat anak cepat sakit atau mudah terserang penyakit \\
\hline & Tuban (tikus hutan) & Makanan tersebut dapat menyebabkan anak cepat sakit atau sering sakit \\
\hline & $\begin{array}{l}\text { Kacang, kelapa, dan } \\
\text { cabe }\end{array}$ & Anak cepat sakit, apalagi batuk dan demam \\
\hline \multirow[t]{2}{*}{$\begin{array}{l}\text { Anak laki-laki yang } \\
\text { dipersiapkan } \\
\text { sebagai tómkót (big } \\
\text { man suku Muyu) }\end{array}$} & $\begin{array}{l}\text { Ketapang, sukun, } \\
\text { nibung, ular, ikan } \\
\text { sembilang, udang, } \\
\text { dan kuskus }\end{array}$ & Kesaktian (waruk) dapat berkurang atau menghilang \\
\hline & $\begin{array}{l}\text { Makanan yang diolah } \\
\text { perempuan }\end{array}$ & 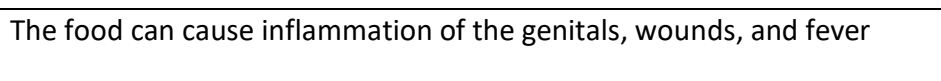 \\
\hline
\end{tabular}

Sumber: Data primer

Jenis burung lain yang menjadi tabu bagi masyarakat Muyu adalah burung tawon-tawon (onkéwét). Burung yang biasa disebut oleh masyarakat di Pulau Kalimantan sebagai paruh besar berwarna kuning ini merupakan pantangan yang berlaku bagi ibu hamil dan menyusui, termasuk anak-anak. Ada kepercayaan yang beredar di kalangan suku Muyu jika larangan mengkonsumsi daging Onkéwét dilanggar, maka akan membuat anak cepat sakit atau mudah terserang penyakit. Selain itu, informan lain juga menyatakan bahwa jika ibu hamil mengkonsumsi daging Onkéwét, juga dapat memberikan efek mono (bisu) pada bayi yang 
dilahirkannya. Kondisinya mirip dengan wanita Muyu yang sedang hamil mengkonsumsi daging atau telur Kasuari.

Jenis burung beo yang oleh masyarakat Muyu biasa disebut sebagai Burung Kauni juga merupakan salah satu jenis makanan yang harus mereka hindari. Pantangan ini berlaku bagi siapa saja, terutama bagi ibu hamil dan menyusui. Kombinasi hitam-putih burung dalam kepercayaan suku Muyu dapat menyebabkan orang cepat terlihat tua karena rambutnya menjadi lebih cepat putih. Jenis produk unggas lainnya yang dinyatakan dilarang adalah telur ayam hutan. Kepercayaan yang berkembang di suku Muyu bahwa telur ayam hutan dapat dengan mudah membuat tubuh anak kecil panas dan kulit gatal.

Tuban atau tikus hutan juga merupakan salah satu makanan hewani yang harus dihindari oleh orang Muyu. Ada kepercayaan di masyarakat Muyu bahwa daging tikus hutan yang bisa tumbuh sebesar kucing dewasa ini bisa membuat tubuh pengkonsumsinya menjadi demam atau panas tinggi. Makan tuban saat hamil bisa menyebabkan anak cepat sakit atau sering sakit. Jika anak Muyu melanggar larangan mengkonsumsi daging tuban, dampak lain dapat menyebabkan pertumbuhan anak menjadi lambat atau terhenti. Pantangan tuban ini berlaku untuk wanita Muyu yang sedang hamil dan menyusui serta pantangan dari anak di bawah empat sampai lima tahun. Anak-anak di atas usia tersebut bebas mengkonsumsi tuban.

Salah satu hewan buruan yang sangat digemari suku Muyu adalah kuskus, padahal hewan ini menjadi pantangan bagi ibu hamil dan ibu menyusui di suku Muyu. Ada dua jenis kuskus yang menjadi pantangan bagi ibu hamil; Pertama, kuskus tanah, orang Muyu dilarang untuk mengkonsumsi karena nantinya dikhawatirkan memiliki anak sebatas hanya dua orang. Menurut informan, spesies kuskus yang hidup di tanah ini memiliki masa reproduksi terbatas, hanya memiliki dua anak sepanjang hidupnya. Jenis kedua adalah kuskus berbulu kuning atau dalam bahasa Muyu biasa disebut dengan omdik birim. Makan daging omdik birim diyakini mempengaruhi bayi yang lahir dari ibu Muyu secara negatif; Orang Muyu mengira akan membuat anak-anak terlahir berkulit kuning.

Salah satu jenis ular, anup kunim, juga tabu bagi wanita Muyu yang sedang hamil. Anup kunim adalah salah satu jenis ular darat. Menurut kepercayaan masyarakat suku Muyu, jika saat hamil akan sulit melahirkan akibat mebgkonsumsi ular jenis ini. Jika ibu hamil muyu makan anup kunim, dapat menimbulkan efek lain yang dapat mendorong tumbuh kembang anak menjadi terganggu dan lambat tumbuh.

Jenis tumbuhan yang paling sering dilarang dikonsumsi oleh para Muyu oleh informan adalah pandan kuning. Pandan kuning merupakan pantangan bagi ibu hamil dan menyusui. Menurut kepercayaan masyarakat Muyu, jika dilanggar maka akibatnya sama saja dengan mengkonsumsi omdik birim (kuskus kuning), membuat anak terlahir berkulit kuning. Kenapa bahwa anak yang lahir kuning itu bermasalah? Orang Muyu secara spontan menjawabnya sebagai sebuah masalah. Mereka tidak ingin anak-anak suku Muyu terlahir kuning, bukan hitam seperti kebanyakan orang Muyu.
Selain pandan kuning, ibu Muyu yang sedang hamil dan menyusui juga sebaiknya menghindari pandan hijau. Mereka menyatakan bahwa jika perempuan melanggar pantangan tersebut, dapat menyebabkan anak yang lahir atau disusui mengalami hambatan bicara atau masalah bicara. Jenis tanaman lain yang menjadi pantangan bagi ibu hamil Muyu adalah mentimun. Tidak ada informasi yang jelas tentang efek atau dampak jika wanita muyu mengkonsumsi jenis sayuran ini.

Jenis pantangan lain untuk ibu hamil dan menyusui adalah daun dan buah-buahan dari sayuran kacang panjang. Makan kacang panjang bisa menyebabkan ASI menjadi kering, sehingga tidak bisa menyusui bayinya. Informan juga menyebutkan gnemo (daun melinjo) sebagai pantangan bagi ibu hamil. Orang Muyu melarang mengkonsumsi gnemo karena bayi dalam kandungan dapat terganggu oleh déma (roh) penjaga kétpòn (tempat suci).

Selain itu, ada juga larangan bagi wanita Muyu yang sedang menstruasi. Orang Muyu melarang keras wanita Muyu yang sedang mengalami haid untuk memakan makanan dari daging babi. Menurut Suku Muyu, mereka percaya daging babi membuat darah haid keluar lebih banyak dari biasanya sehingga haid bisa lebih lama. Mereka beranggapan darah babi itu bersifat panas. Pantangan makanan untuk anak-anak, terutama untuk anak laki-laki, juga hampir sama dengan pantangan bagi pria Muyu dewasa. Pantang ini berlaku untuk anak laki-laki yang mereka persiapkan untuk menjadi tómkót, terutama saat menjalani proses inisiasi. Sebelum memulai proses inisiasi, para calon tómkót harus menjalani beberapa jenis pantangan makanan. Suku Muyu melarang buah dan hewan tertentu (amóp), termasuk ketapang, sukun, nibung, ular, ikan sembilang, udang, dan kuskus.

Selain pantangan terhadap jenis makanan tertentu, mereka juga melarang anak laki-laki Muyu yang memulai inisiasi menjadi tómkót untuk makan makanan yang dimasak oleh perempuan. Walaupun mereka memasak makanan yang tidak termasuk kelompok makanan pantangan, pelanggaran terhadap pantangan tersebut akan menyebabkan penyakit pada anak laki-laki, yaitu radang alat kelamin, luka, dan demam ${ }^{11}$.

Secara umum, anak kecil harus menghindari beberapa makanan. Kali ini makanan pantangan ini tidak terkait dengan proses inisiasi untuk menjadi tómkót. Makanan tersebut adalah kacang-kacangan, kelapa, dan merica. Anak-anak sebaiknya menghindari pantangan makanan seperti ini agar tidak cepat sakit, terutama batuk dan demam ${ }^{18}$

Suku Muyu menentukan beberapa pantangan makanan berdasarkan ciri fisik makanan tersebut. Misalnya, pantangan makanan berwarna kuning karena khawatir perempuan Muyu akan melahirkan anak berkulit kuning. Pada prinsipnya, situasi ini sama dengan konsep makanan tabu yang dilaporkan dalam penelitian di suku Tengger sebelumnya. Selain itu, masyarakat Muyu juga akrab dengan ide makanan pantangan karena bersifat panas. Bedanya, makanan panas suku Tengger berlaku untuk ibu hamil, sedangkan di suku Muyu berlaku untuk wanita yang sedang haid6. 


\section{Makanan Pantangan: Antara Risiko dan Proteksi}

Menghindari makanan tertentu yang berlaku bagi seluruh masyarakat Muyu dapat berdampak pada kesehatan. Ibu menyusui, ibu hamil, dan anak-anak merupakan kelompok yang paling rentan. Mereka adalah sasaran paling sering diteliti berkaitan dengan efek dari pantangan makanan. Penyebab kerawanan selama periode tersebut karena kebutuhan nutrisi yang meningkat. Beberapa penelitian menginformasikan bahwa pantangan makanan dapat menyebabkan kekurangan gizi, terutama pada ibu hamil dan menyusui ${ }^{19-21}$.

Orang Muyu harus menghindari makanan pantangan. Beberapa suku tertentu meyakini menghindari makanan tertentu karena efek merusak dari makanan tersebut jika dikonsumsi. Informasi dari beberapa hasil penelitian sebelumnya menemukan hasil sebaliknya. Tidak makan makanan tertentu dapat memiliki konsekuensi berbahaya, seringkali menjadi kekurangan gizi, termasuk anemia ${ }^{22-24}$. Makanan pantangan membuat variasi pilihan makanan menjadi terbatas. Kondisi ini membuat asupan makanan kurang dari yang seharusnya ${ }^{21,25}$.

Ibu hamil yang berpantang terhadap jenis makanan tertentu seringkali menjadikan ibu hamil rentan mengalami gizi buruk, meski tidak selamanya bersifat buruk. Beberapa praktik berpantang makanan memiliki sisi positif. Tidak mengonsumsi makanan tertentu berpotensi menghindari kebiasaan makan yang tidak sehat ${ }^{4}$. Berpantang makan daging babi untuk wanita Muyu misalnya, bisa menghindari makanan berlemak untuk mencegah kelebihan berat badan ${ }^{26}$. Beberapa penelitian lain juga melaporkan bahwa berpantang makanan laut dapat menghindari alergen dan kolesterol berlebihan ${ }^{5}$. Berpantang mengkonsumsi makanan laut adalah pencegahan, karena makanan laut dikenal sebagai alergen yang kuat. Makanan laut dapat memicu reaksi merugikan yang disebabkan oleh antibodi imunoglobulin E pada individu yang sensitif ${ }^{27}$.

\section{KESIMPULAN}

Makanan pantangan berlaku khusus untuk semua anggota masyarakat suku Muyu. Makanan pantangan untuk pria paling erat kaitannya dengan praktik ritual karena menjalani inisiasi sebagai tómkót (big man). Sementara itu, oranag Muyu memaksudkan pantangan makanan bagi perempuan, seringkali karena kondisi hamil dan menyusui. Makanan pantangan bagi ibu hamil Muyu sering dikaitkan dengan janin dalam kandungan. Tabu makan untuk anak-anak, terutama bagi anak laki-laki, hampir sama dengan pantangan bagi pria Muyu dewasa. Pantang ini berlaku untuk anak laki-laki yang dipersiapkan untuk menjadi tómkót, terutama saat menjalani proses inisiasi. Bagi anak laki-laki dalam inisiasi, pantangan tidak hanya didasarkan pada jenis bahan makanan yang tabu tetapi juga pada makanan yang diolah oleh wanita.

\section{ACKNOWLEDGEMENT}

Penulis mengucapkan terima kasih kepada masyarakat Suku Muyu di Papua Indonesia yang telah menyambut penulis dengan tangan terbuka, dan Kementerian Kesehatan RI atas terselenggaranya penelitian ini.

\section{REFERENS}

1. Meyer-Rochow, V. B. Food taboos. in Encyclopedia of Food Security and Sustainability 332-335 (Elsevier, 2018). doi:10.1016/B978-008-100596-5.22233-6

2. Triratnawati, A. Food taboos and codes of conduct for pregnant women at Mount Sindoro, Wonosobo district, Central Java, Indonesia. Stud. Ethno-Medicine 13, 22-32 (2019).

3. Chakona, G. \& Shackleton, C. Food taboos and cultural beliefs influence food choice and dietary preferences among pregnant women in the eastern Cape, South Africa. Nutrients 11, Article number 2668 (2019).

4. Iradukunda, F. Food taboos during pregnancy. Health Care Women Int. 41, 1-10 (2020).

5. Diana, R. et al. Food taboos and suggestions among Madurese pregnant women: a qualitative study. J. Ethn. Foods 5, 246-253 (2018).

6. Sholihah, L. A. \& Sartika, R. A. D. Taboo Foods for Pregnant Women in the Tengger Tribe (Makanan Tabu pada Ibu Hamil Suku Tengger). J. Kesehat. Masy. Nas. 8/7, 319-324 (2014).

7. Laksono, A. D. Tengger Bertahan dalam Adat: Studi Konstruksi Sosial Ukuran Keluarga Suku Tengger. (Health Advocacy, 2020).

8. Ekwochi, U. et al. Food taboos and myths in South Eastern Nigeria: The belief and practice of mothers in the region. J. Ethnobiol. Ethnomed. 12, Article number 7 (2016).

9. Central Bureau of Statistics of Indonesia. Citizenship, Ethnicity, Religion, and Everyday Language Indonesian Residents. Results of the 2010 Population Census. (2011).

10. Laksono, A. D. Anyiman: Ethnographic Study of Muyu Tribal Foods (Anyiman: Studi Etnografi Makanan Suku Muyu). (PT Kanisius, 2015).

11. Schoorl, J. W. W. Culture and Change in the Muyu Tribe in the flow of Modernization of Irian Jaya (Kebudayaan dan Perubahan Suku Muyu dalam Arus Modernisasi Irian Jaya). (Grasindo, 1997).

12. Kusumawardani, N. et al. Qualitative Methods for Health Research (Penelitian Kualitatif di Bidang Kesehatan). (PT Kanisius, 2015).

13. Spradley, J. The Ethnographic Interview. (Wadsworth, 1979).

14. Laksono, A. D., Soerachman, R. \& Angkasawati, T. J. Case Study of Muyu Ethnic's Maternal Health in Mindiptara District-Boven Digoel (Studi Kasus Kesehatan Maternal Suku Muyu di Distrik Mindiptana, Kabupaten Boven Digoel). J. Reprod. Heal. 07/03, 145-155 (2016).

15. Laksono, A. D., Faizin, K., Raunsay, E. M. \& Soerachman, R. Muyu women in exile (Perempuan Muyu dalam Pengasingan). (Lembaga Penerbitan Balitbangkes, 2014).

16. Laksono, A. D. \& Faizin, K. Traditions Influence Into Behavior in Health Care; Ethnographic Case 
Study on Health Workers Muyu Tribe. Bull. Heal. Syst. Res. 18, 347-354 (2015).

17. Rumlus, E. Penggunaan Kekuatan-Kekuatan Gaib dalam Suku Muyu (Irja). (Pusat Pastoral Jogjakarta, 1980).

18. Laksono, A. D., Dewi, Y. S. \& Wulandari, R. D. Muyu tribes' local wisdom: complimentary care for limited health access. Eurasian J. Biosci. 14, 5871-5878 (2020).

19. Placek, C. D., Madhivanan, P. \& Hagen, E. H. Innate food aversions and culturally transmitted food taboos in pregnant women in rural southwest India: Separate systems to protect the fetus? Evol. Hum. Behav. 38, 714-728 (2017).

20. Tobing, V. Y., Afiyanti, Y. \& Rachmawati, I. N. Following the cultural norms as an effort to protect the mother and the baby during the perinatal period: An ethnographic study of women's food choices. Enferm. Clin. 29, 831836 (2019).

21. Basir, S. M. A. et al. Dietary intake of mothers who practised traditional confinement during exclusive breastfeeding period. Malaysian J. Med. Heal. Sci. 15, 39-46 (2019).

22. Riang'a, R. M., Broerse, J. \& Nangulu, A. K. Food beliefs and practices among the Kalenjin pregnant women in rural Uasin Gishu County, Kenya. J. Ethnobiol. Ethnomed. 13, Article number 29 (2017).

23. Asi, L. N., Teri, D. T. \& Meyer-Rochow, V. B. Influence of food taboos on nutritional patterns in rural communities in Cameroon. Int. Rev. Soc. Res. 8, 2-6 (2018).

24. Mohammed, S. H., Taye, H., Sissay, T. A., Larijani, B. \& Esmaillzadeh, A. Teff consumption and anemia in pregnant Ethiopian women: a casecontrol study. Eur. J. Nutr. 58, 2011-2018 (2019).

25. Mohammed, S. H., Taye, H., Larijani, B. \& Esmaillzadeh, A. Food taboo among pregnant Ethiopian women: Magnitude, drivers, and association with anemia. Nutr. J. 18, Article number 19 (2019).

26. Arzoaquoi, S. K. et al. Motivations for food prohibitions during pregnancy and their enforcement mechanisms in a rural Ghanaian district. J. Ethnobiol. Ethnomed. 11, Article number 59 (2015).

27. Prester, L. Seafood Allergy, Toxicity, and Intolerance: A Review. J. Am. Coll. Nutr. 35, 271283 (2016). 